\title{
THE LAST WORD
}

By Edward L. Korwek

\section{DELIBERATE RELEASE: A LEGAL OPINION}

"So I leave it with all of you: which came out of the opened door, the lady or the tiger?"

-Frank R. Stockton, The Lady or The Tiger

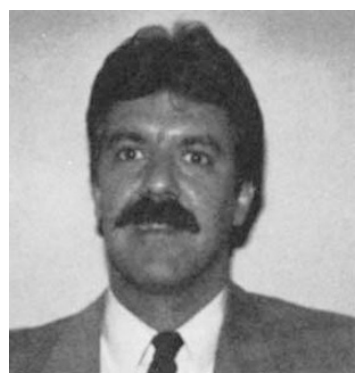

Edward L. Korwek

approve experimentation of recombinant DNA..."

The Foundation on Economic Trends, headed by environmental activist and rDNA research critic Jeremy Rifkin, had filed suit in federal district court to block the NIH from giving further approval for deliberate release of genetically modified organisms. Invoking the National Environmental Policy Act (NEPA) and the Administrative Procedure Act (APA), the Foundation argued that NIH failed to file an environmental impact statement or environmental assessment when revising its 1978, 1982, and 1983 Guidelines for Recombinant DNA Research involving deliberate release. The court concurred that NIH had not followed proper procedures under either NEPA or APA when deciding that the 1978 revision of the Guidelines had no significant environmental impact.

While the legal bases for the decision are fairly straightforward, the ramifications for deliberate release experiments are not. For example, as stated the decision applies only to institutions and investigators receiving government funding. The court specifically prohibited field tests by University of California researcher Steven Lindow, who proposed spraying potato plants with a strain of bacteria genetically engineered to reduce frost damage. However, the court's order specitically exempts experiments by private firms, holding that companies voluntarily seeking NIH approval are not within NIH's compulsory jurisdiction. The court thus created a legal distinction based on whether compliance with the Guidelines is voluntary or mandatory.

The court's selective treatment of deliberate release experiments precipitated-not unexpectedly-a decision by the Recombinant DNA Advisory Committee (RAC) to approve privately funded experiments similar to those barred by Judge Sirica. Two weeks after the preliminary injunction (but before a trial on the merits of the plaintiffs' claims) RAC recommended approval of a proposal from Advanced Genetic Sciences Inc. for deliberate-release frost-control experiments to NIH Director James Wyngaarden. They also recommended approval of field tests of genetically engineered plants by Cetus Madison Co.

RAC's decisions were entirely consistent with previous approvals and with Judge Sirica's order. There was no scientific evidence that the experiments pose a health or environmental hazard, and the court's decision did not prohibit NIH approval of privately funded deliberate release experiments. At this writing, Wyngaarden has not given final approval of either project, and on June 11 the Foundation filed a motion seeking a preliminary injunction barring the Advanced Genetic Sciences experiments.

Judge Sirica's order follows the letter of the law and the judicial maxim of ruling on the narrowest possible grounds. The decision primarily addresses the procedural flaws in the NIH process of modifying and developing Guidelines governing release of genetically manipulated organisms. But if NIH approval is procedurally defective under NEPA, then it is defective regardless of the source of funding for the experiments.

The legal distinction between government and privately funded projects created by the decision-whether valid or not-raises the perplexing question of which federal agencies, if any, have authority to regulate genetic manipulation. Judge Sirica stated he was "unpersuaded" on the materiality of the Federal Insecticide, Fungicide and Rodenticide Act (FIFRA), which falls under Environmental Protection Agency jurisdiction. Pesticides cannot be registered under FIFRA if they pose unreasonable environmental hazards. Thus the environmental goals of NEPA and FIFRA are similar, and registration under FIFRA may well be practically relevant to a decision on envirorimental impact under NEPA.

The court's decision raises more issues than it resolves. This is not surprising since the judiciary often takes a narrow view of the world, defining problems via specific legal "filters" and issuing decisions on the facts of individual cases. If comprehensive oversight of genetic manipulation-and the specific problem of deliberate release-is desirable, regulatory action based on a broader perspective is needed. Inadequate or deferred regulation does not necessarily foster technological growth.

Edward L. Korwek, Ph.D., J.D., is associated with the law offices of Keller and Heckman, 1150 17th Street, N.W., Washington, D.C. 20036. 